\title{
Cannabis in Asia: its center of origin and early cultivation, based on a synthesis of subfossil pollen and archaeobotanical studies
}

\author{
JOHN M. MCPARTLAND ${ }^{1,2 *}$, WiLliam HEGMAN ${ }^{3}$, AND TENGWEN LONG ${ }^{4}$ \\ ${ }^{1}$ University of Vermont, Burlington, Vermont, USA \\ ${ }^{2}$ GW Pharmaceuticals, Sovereign House, Histon, Cambridge, CB24 9BZ, UK \\ ${ }^{3}$ Department of Geography, Middlebury College, Middlebury, Vermont, 05753, USA \\ ${ }^{4}$ School of Geographical Sciences, University of Nottingham Ningbo China, Ningbo, 315100, \\ China \\ *corresponding author, telephone 802-388-8304, e-mail: mcpruitt@ myfairpoint.net
}

\begin{abstract}
Biogeographers assign the center of origin of Cannabis to "Central Asia," mostly based on wildtype plant distribution data. We sought greater precision by adding new data: 155 fossil pollen studies (FPSs) in Asia. Many FPSs assign pollen of Cannabis or Humulus $(C-H)$ to collective names (e.g., Cannabis/Humulus or Cannabaceae). To dissect these aggregate data, we used ecological proxies. $\mathrm{C}$ - $\mathrm{H}$ pollen in a steppe assemblage (with Poaceae, Artemisia,

Chenopodiaceae) was identified as wild-type Cannabis. $C$ - $H$ pollen in a forest assemblage (Alnus, Salix, Quercus, Betula, Robinia, Juglans) was identified as Humulus. C-H pollen curves that upsurged alongside crop pollen were identified as cultivated hemp. Subfossil seeds (achenes) at archaeological sites also served as evidence of cultivation. FPSs and archaeological sites were mapped using geographic information system (GIS) software. The oldest $C$ - $H$ pollen consistent with $C$. sativa dated to 19.6 million years ago (mya), in northwestern China. However, Cannabis and Humulus diverged 27.8 mya, based on molecular clock analysis. We bridged the temporal gap between the divergence date and the oldest pollen by mapping the earliest appearance of Artemisia. These data converge on the northeastern Tibetan Plateau, which we deduce as the $C$. sativa center of origin. This co-localizes with the first steppe community that evolved in Asia. From there, Cannabis first dispersed west (Europe by 6 mya) then east (eastern China by 1.2 mya). Cannabis pollen in South Asia appeared by 32.6 kya. The earliest Cannabis seeds were found in Japan, 10,000 BCE, followed by China.
\end{abstract}


Keywords: Cannabis sativa; Humulus lupulus; Cannabaceae; biogeography; center of origin; GIS

Electronic supplementary material The online version of this article contains supplementary material, which is available to authorized users.

\section{Introduction}

Cannabis sativa L. holds significance in human history and life today as a triple-use crop. First, its fruits (seeds) provide valuable protein and essential fatty acids. Archaeological evidence in a food context dates back to 10,000 BP, in Japan (Kobayashi et al. 2008). Its bast cells supply fiber, for cordage and textiles. Carbonized hemp fiber, found with silk and spinning wheels, dates to 5600 BP, in Henan Province, China (Zhang and Gao 1999). Its flowering tops produce cannabinoids, which have been used for medicinal, shamanic, and recreational purposes. Archaeological evidence of drug use dates to 2700 BP, in Xinjiang Region (Russo et al. 2008, Jiang et al. 2016).

Despite a voluminous literature emerging in the last three decades, the classification of Cannabis and its center of origin remains under continuous debate. A single species concept (Small and Cronquist 1976), has support from measures of population differentiation, such as $\mathrm{F}_{\mathrm{ST}}$ (Sawler et al. 2015, Lynch et al. 2016) and barcode gaps (McPartland 2018). Other botanists recognize several species in the genus Cannabis (Hillig and Mahlberg 2004, Clarke and Merlin 2013). Hypotheses regarding the Cannabis center of origin began with Ibn Wahshīyah in 930 CE. He proposed that $\check{s} \bar{a} h d \bar{a} n a j$ was brought to Babylon from India and perhaps China (HämeenAnttila 2006). De Candolle (1884) offered Central Asia as the center of origin of $C$. sativa. His biogeographical theories were based upon the distribution of wild-type plants, as well as linguistic, historical, archaeological, and fossil data.

Print fossils (i.e., impressions of leaves or fruits in rocks) of $C$. sativa are limited to only two collections: Friedrich $(1883 a, b)$ found fossil leaves in Germany that he named Cannabis oligocaenica. His species epithet indicates the Oligocene Epoch, 33.9-23.03 million years ago (mya). Palamarev (1982) identified a fossil seed (achene) as "Cannabis sp." in Bulgaria. He dated the find to the late Miocene ("Pontian age", 7.3-5.3 mya). Dorofeev (1969) reported a fossil seed, "Cannabis sp.," from the Miocene in Siberia. He subsequently reidentified the fossil 
as an extinct species, Humulus irtyshensis (Dorofeev 1982). Humulus and Cannabis are sister genera, forming a phylogenetic clade within the family Cannabaceae.

Contrary to the paucity of print fossils, hundreds of fossil pollen studies (FPSs) have identified subfossil Cannabis pollen. Fröman (1939) first used pollen analysis to reconstruct the history of Cannabis. Following analytical refinements by Fries (1958), dozens of papers have been published. This culminated with the elaborate meta-analysis by Dörfler (1990), followed by our own meta-analyses (Long et al. 2017, McPartland et al. 2018).

Cannabis pollen is often straightforward to recognize (Mercuri et al. 2002), however, morphological similarities between Cannabis and Humulus pollen grains have prompted palynologists to use collective labels, e.g., Cannabis/Humulus or Cannabaceae. Significant labeling bias also arises: Chinese FPSs palynologists assign Cannabis pollen to "Humulus" (Li 1974), and northern European palynologists often assign Humulus pollen to "Cannabis" (Wilson 1975).

Parsing Cannabis from Humulus may be more difficult in Asia than in Europe. Five palynology studies of Asian Cannabis (C. sativa subsp. indica) indicate that pollen grain diameter is smaller than that of European hemp ( $C$. sativa subsp. sativa), so the size of Asian Cannabis pollen falls within the range of Humulus (literature in McPartland et al. 2018).

FPSs resorting to collective labels (hereafter abbreviated $C$ - $H$ pollen) have thwarted the study of Cannabis. Clarke and Merlin (2013) reviewed dozens of Asian FPSs, and they were flummoxed by FPSs that lumped data as $C-H$ pollen. Long et al. (2017) synthesized 46 FPSs in their pan-Eurasian study. They resolved the $C-H$ dilemma by limiting FPSs to studies that explicitly identified pollen as Cannabis - a strategy that excluded a lot of $C$ - $H$ data.

McPartland et al. (2018) used ecological proxies, instead of grain morphology, to differentiate $\mathrm{C}-\mathrm{H}$ pollen as either Cannabis or Humulus pollen. Cannabis flourishes in steppean open, treeless habitat. European phytosociologists and other field botanists report wild-type $C$. sativa cohabitating with Poaceae, Artemisia, and Chenopodiaceae (hereafter abbreviated PAC). Thus $C-H$ pollen in a steppe assemblage (with $P A C$ pollen) was identified as wild-type Cannabis. Conversely, Humulus lupulus, a perennial herbaceous scandent, requires trees to climb. European phytosociologists and other field botanists report $H$. lupulus associating with Alnus, Populus, and Salix spp. (abbreviated ASP). Thus $C$ - $H$ pollen in a mesophytic forest assemblage (with ASP pollen) was identified as Humulus. 
Palynologists have noted correlations between Cannnabis and PAC, and between Humulus and $A S P$, and extended these associations into the past. For supporting palynological and phytosociological literature, see McPartland et al. (2018). In this study, we aim to further develop this method, focusing in particular on the Asia context. The ecological proxies method will be applied to a multilingual collection of Asian FPSs to reconstruct the evolutionary and human-related history of Cannabis in Asia.

\section{Methods}

\section{FPS search strategy and data analysis}

We collated an FPS database using several internet search engines (European Pollen Database, Web of Science, Google Scholar) using keywords and Boolean operators: Asia AND (palynology OR pollen) AND (Cannabis OR Humulus OR Cannabaceae). This was repeated with Chinese characters when searching Chinese-based references. Additional FPSs were obtained through citation tracking — references in retrieved publications were searched for antecedent sources, and these were retrieved. To map pollen in space and time, retrieved publications had to meet three inclusion criteria: 1) precise geographical coordinates, 2) accurate chronology, 3) a minimal threshhold amount of pollen grains.

1. Precise geographical coordinates were localized to within a hundredth degree of latitude and longitude. Some studies did not provide geographical coordinates. We obtained coordinates of those sites via Google Earth, which uses World Geodetic System of 1984 (WGS84) datum. Several FPS were conducted at deep-water sites, which explains sites located in seas and oceans. Geographers have debated the border between eastern Europe and western Asia. We included three studies on the edge: a deep-water site in the Black Sea off the coast of Turkey, a site in Georgia, and a cis-Ural site in Russia.

2. Accurate chronology necessitated restricting data to FPSs with absolute dating, such as radiocarbon $\left({ }^{14} \mathrm{C}\right)$, optically stimulated luminescence (OSL), or magnetostratigraphical methods. We excluded studies that assigned "relative dates" within sediments cores (i.e., dates inferred by changes in vegetation, such as the start of the Holocene).

3. Palynologists debate the minimal amount of pollen required to determine the local presence of a plant species at a study site (versus pollen at a study site that arrived via long distance transport). Botemma et al. (2003) specifically mentioned $C$ - $H$ pollen in the "problem of 
long-distance transport." Several FPSs located in southwestern Asia had three or fewer $C$ - $H$ pollen grains. These rare grains likely blew in from Europe. The Etesian winds blow from the Balkans (harboring endemic Cannabis) into Israel, Palestine, Lebanon, and Egypt (Zecchetto and De Blasio 2007). For a retrieved publication to be included in our study, $\mathrm{C}-\mathrm{H}$ pollen had to appear in a minimum of five separate strata within a stratigraphic core (for details see McPartland et al. 2018).

\section{Ecological proxies in the Asia context}

In Central and East Asia, Cannabis seems to have a stronger alliance with Artemisia, less so with Poaceae and Chenopodiaceae. We took a closer look at Artemisia, to better pin-point the Cannabis center of origin. Artemisia and Cannabis share parallel evolutionary patterns: In phylogenetic studies, Artemisia nests within the Antemideae subfamily (Zhao et al. 2010), and Cannabis nests within the Cannabaceae family (Yang et al. 2013). Artemisia evolved in Central/East Asia during the late Eocene (ca.36-33.9 mya) out of the worldwide Antemideae (Miao et al. 2011). Cannabis also evolved in Central/East Asia, ca. 27.8 mya, out of the worldwide Cannabaceae (McPartland 2018).

Artemisia and Cannabis are wind-pollinated and dioecious. Both genera exhibit phenotypic plasticity, with adaptive phenotypes that respond to environmental changes, enabling them to colonize new geographic locations. A meta-analysis of FPSs in Europe showed that Cannabis and Artemisia were fellow travelers; their geographic ranges expanded and contracted in unison during, respectively, glacial periods and warmer periods (McPartland et al. 2018).

Humulus pollen, in Central and East Asia, correlates with ASP pollen, as well as Quercus, Betula, Juglans, Camellia, and Robinia (abbreviated ASP+). Analyzing Humulus pollen in East Asia is complicated by two additional species, $H$. yunnanensis and $H$. japonicus $(=H$. scandans). H. yunnanensis is a tree-climbing species limited to Yunnan province (Zhou and Bartholomew 2003). It is a rare and endangered plant ( $\mathrm{Hu}$ and $\mathrm{Wu}$ 1992). No phytosociological studies have been published that include $H$. yunnanensis.

H. japonicus is native to Japan, Korea, and eastern China (Zhou and Bartholomew 2003), the Russian Far East (Maximovich 1859), and Vietnam and Laos (Pételot 1954). Phytosociological and field studies report $H$. japonicus in communities dominated by trees-specifically Alnus (Lee et al. 1976, Kim et al. 2010, Jeong et al. 2012, Lee et al. 2013), Salix (Kolbek and 
Karolímek 2008, Kim et al. 2010, Oh et al. 2010, Jeong et al. 2012, Lee et al. 2013), Quercus (Lee et al. 1976, Kolbek and Karolímek 2008, Kim et al. 2010, Oh et al. 2010), Robinia (Lee et al. 1976, Kolbek and Karolímek 2008, Kim et al. 2010, Jeong et al. 2012, Lee et al. 2013, Lee and Ahn 2014), and Camellia (Kim et al. 2010, Lee et al. 1976, Lee and Ahn 2014, Eom and $\operatorname{Kim} 2017)$.

However, H. japonicus sometimes colonizes habitats that overlap with those of C. sativa. These include ruderal communities (Kolbek and Sádlo 1996, Oh et al. 2008), and riverside communities (Jung and Kim 1998). Some riverside communities include Poaceae, Artemisia, or Chenopodiaceae in the ground layer (Balogh and Dancza 2008, Andrek et al. 2010, Song and Song 1996, Jarolímek and Kolbek 2006). One phytosociological study reports H. japonicus colocalizing with C. sativa - a ruderal community in Korea (Kolbek and Sádlo 1996). Maximovich (1859) reported H. japonicus growing with $C$. sativa in the Amur region of the Russian Far East, and Clarke and Merlin (2013) photographed feral hemp and H. japonicus growing together in Shandong Province.

Despite these intermittent associations with herbaceous plants, Asian paleobotanists characterize Humulus as a drought-intolerant climber of trees (Ni et al. 2010). They treat Humulus pollen as a botanical marker of deciduous broadleaved forests (Zhou et al. 2007), or tropical evergreen forests (Lee and Liew 2010).

The ratio of nonarboreal pollen (NAP, pollen from grasses, forbs, and sedges) and arboreal pollen (AP, tree pollen) serves as an indicator of landscape openness. NAP and AP percentages are oppositional—when one goes down, the other goes up. Similarly, palynologists have shown that Alnus and PAC demonstrate oppositional characters (literature in McPartland et al. 2018).

$\mathrm{CH}$ pollen can be identified as that of cultivated hemp when its pollen count surges or becomes a continuous curve in synchrony with pollen from other crop plants. This metric was first adopted by Fries (1958) and used in ten other palynological studies. Other crop plants include Avena (oats), Hordeum (barley), Secale (rye), Triticum (wheat), and Cerealia-type (undifferentiated cereal pollen).

The presence of Cannabis pollen in very high percentages indicates a former hemp retting site. Retting is a technical term for rotting, a process that separates fibers from the rest of the stalk. Soaking hemp stalks in water encourages bacterial growth and retting. When flowering male plants are soaked in a retting pond, large quantities of pollen settle into pond sediments. 
Cannabis pollen $\geq 15 \%$ of TLP (total land pollen) is usually considered evidence of hemp retting, and percentages up to $97 \%$ have been reported (literature in McPartland et al. 2018).

\section{Pollen algorithm}

To differentiate $C-H$ pollen, the algorithm by McPartland et al. (2018) was adjusted to account for Asian conditions. We identified $C$ - $H$ pollen as that of cultivated $C$. sativa when it appeared de novo along with crop pollen, or increased at least 2-fold over earlier pre-Neolithic counts. Several FPSs in South Asia report Cerealia pollen, attributed to agriculture, in ancient strata that clearly predate archaeological evidence of grain cultivation (e.g., 12,000 BP, Quamar and Bera 2017). In these FPSs we looked for 2-fold increases and continuous curves of $C-H$ pollen in the presence of Cerealia pollen.

To differentiate $C$ - $H$ pollen in pre-agricultural strata, we used ecological proxies. When $C-H$ occurred in a pollen assemblage where the NAP-to-AP ratio $\geq 2$ (i.e., $\geq 66 \% / 33 \%$ ), dominated by steppe vegetation $(P A C)$, we identified it as wild-type Cannabis. When $C$ - $H$ occurred in a pollen assemblage where the NAP/AP ratio $\leq 0.5$ (i.e., $\leq 33 \% / 66 \%$ ), in the presence of $A S P+$, we identified it as Humulus. In some ambiguous FPSs, pollen counts of PAC and ASP+ rise and fall in near-synchrony, and the NAP/AP ratio approaches 1:1 (i.e., 50\%/50\%). At these sites, we classified $C$ - $H$ pollen as unresolved $C / H$.

\section{Archaeobotanical evidence}

We also included botanical evidence from archaeological sites. Previous studies have collated archaeological reports of hemp seeds, phytoliths, stalk fragments, fiber, cordage, or textiles, and pottery impressions of those materials (Clarke and Merlin 2013, Long et al. 2017). McPartland and Hegman (2018) stratified the relative robustness or validity of these materials. Microscopically-analyzed seeds, phytoliths, and stem fragments were considered the most robust evidence. Fiber, cordage, and textiles were problematic. For example, Song et al. (2017) unearthed a few plant fibers identified as hemp, $C$. sativa, at a site occupied by Paleolithic hunter-gatherers that dates to 28.5 kya. This could be the oldest hemp fiber ever found, but their photomicrograph of a "hemp" fiber is by no means convincing. Song et al. (2017) report plentiful flax fibers at their site. McPartland and Hegman (2018) detail the difficulties in differentiating hemp from flax fiber. Regarding pottery impressions, identifying the plant species 
that made the cord impression is even more difficult. At least 14 plant species were utilized for pottery cord impressions in Neolithic China (Kuhn 1988). In this current study, we limited archaeological findings to microscopic analyses of seeds, phytoliths, and stem fragments.

\section{GIS mapping and binning strategy}

Latitude and longitude (referencing WGS84 datum) of each FPS was plotted, using geographic information system (GIS) software, ArcGISPro 2.2. The FPS sites were plotted on three maps, corresponding to three binned time slices. Each FPS site was notated with a symbol indicating pollen interpretation-either wild-type Cannabis, Humulus, cultivated Cannabis, or unresolved $\mathrm{C} / \mathrm{H}$ pollen. Archaeological sites with hemp seeds or phytoliths were notated with another symbol.

Stratigraphical data were binned into three time slices:

Bin 1. This period includes the Oligocene (33.9-23.03 mya), Miocene (23.03-5.3 mya), Pliocene (5.3-2.58 mya), and Pleistocene (2.58 mya-11.6 thousand years ago, kya) epochs. The symbols for these sites are sized according to the age of the pollen. A weighted centroid for Cannabis pollen data was also calculated (weighted by geographical location and age).

Bin 2. Early- to Mid-Holocene, 11.5-5.0 kya, a period of improved climate, reemerging forests, and the Mid-Holocene Climatic Optimum. This period includes the onset of agriculture in Asia and the earliest archaeobotanical evidence of Cannabis usage.

Bin 3. Late-Holocene, 4.5-0 kya, a period of profound anthropogenic impact on landscapes, and the earliest recorded Asian history.

\section{Extrapolating into the Oligocene}

McPartland (2018) constructed a maximum likelihood phylogenetic tree (PAUP* version 4.0b10) of 11 Rosales genera, using $r b c L+t r n L-t r n F$ sequences, and a nonparametric variable rate-smoothing algorithm (r8s version 1.70), calibrated with four fossil date intervals (Boehmeria 60-34 mya, Morus 56-34 mya, Celtis 65-56 mya, Humulus 28-16 mya). The molecular clock estimated that Cannabis and Humulus evolved (diverged) 27.8 mya. This date considerably predates the oldest Cannabis pollen found in this study (19.6 mya). To deduce the location of $C$. sativa during this temporal "missing link," we used two sets of indirect data: 
Bosboom et al. (2011) mapped an "aridification zone" arising in Central Asia at the EoceneOligocene boundary, 34 mya. Orogenic changes at that time - the rise of the Tibetan plateau and the retreat of the Tarim Sea-forced concomitant changes in climate, resulting in the evolution of steppe vegetation. China's first steppe communities originated at the Eocene-Oligocene boundary (Sun et al. 2014), and continued to develop through the Oligocene and Miocene (Wang 1996), spanning the temporal missing link. We transferred a best approximation of the paleogeographic map by Bosboom and colleagues onto a modern map of Asia.

Secondly, we applied a previously reconstructed history of Artemisia in Asia. Miao et al. (2011) tracked the spatiotemporal appearance of Artemisia pollen, beginning at the EoceneOligocene boundary, in a meta-analysis of 122 FPSs. As a proxy for the distribution of Cannabis prior to our oldest pollen, we mapped their distribution of Artemisia pollen, in six binned time slices used by Miao and colleagues: late Eocene (38-34 mya), latest Eocene (34 mya), early Oligocene (34-28 mya), Oligocene (34-23 mya), early Miocene (23-20 mya), and mid-Miocene (14 mya).

\section{Results}

The search strategy identified 173 FPSs that included $C-H$ pollen or archaeological studies with seeds, phytoliths, or stem fragments. Seven studies did not meet our inclusion criteria, and another eleven studies reported duplicate data. The remaining 155 studies were tabulated, each with a citation number, study location, details regarding application of the algorithm, and duplicate reports (Online Resource, Table S1). Excluded studies were also tabulated, with exclusion criteria (Table S2).

Bin 1 (19.6 mya-11.6 kya, Fig 1). The oldest $C-H$ pollen consistent with Cannabis dated to 19.6 mya (early Miocene). The site is located in Ningxia, China, on the border between the Tibetan Plateau and the Loess Plateau. For scholars interested in the original publication, see Table S1, citation \#1. During the Pliocene, Cannabis pollen occurs in Northwest China (Ningxia, 2.6 mya, Table S1, \#2). During the first half of the Pleistocene (i.e., the Gelasian and Calabrian ages, 2.58 mya-781 kya), Cannabis pollen is located in Bashkorostan, Russia (1.5 mya \#156), Hebei Province (1.2 mya \#3), and the Russian Altai (787 kya, \#4).

During the latter half of the Pleistocene, Cannabis pollen appears in four of six Chinese regions: Northwest China (Shaanxi, 342 kya, \#5; Gansu, 145 kya, \#6; Shaanxi, 50 kya, \#8; 
Shaanxi, 25 kya, \#12; Tibet, 20 kya, \#13; Xinjiang, 14.5 kya, \#20; Gansu, 12 kya, \#28). North China (Inner Mongolia, 35 kya, \#9). Northeast China (Liaoning, 16 mya, \#16; Jilin, 13 kya, \#24). East China (Shanxi, 15 kya,\#19). FPSs in two remaining provinces, South Central and Southwest China, have Humulus pollen but no Cannabis pollen.

FPSs from latter half of the Pleistocene show sites with Cannabis pollen elsewhere in East Asia (Korea, 32 kya, Table S1 \#10); as well as Kazakhstan (130 kya,\#152), Southwest Asia (Turkey, 111 kya, \#7; Black Sea near Turkey, 17 kya, \#152; Caspian Sea near Iran, 14 kya, \#23; Georgia, 13 kya, \#154; Syria, 11.9 kya, \#30); South Asia (India, 32.6 kya, \#11; Sri Lanka, 18 kya, \#14; India, 12.8-11.9 kya, \#25, \#26, \#27, \#29); and Central Siberia (Altai, 16-15 kya, \#15, \#17, \#18).

One FPS in Bin 1 (Table S1, \#9) conflicted with our algorithm's designation of a retting site (Cannabis pollen $\geq 15 \%$ of TLP). That study reported $C-H$ pollen reaching $61 \%$, but it was clearly not a retting site, because it occurred $34 \mathrm{kya}$, long before agriculture began. The shortlived $C$ - $H$ pollen spike was superseded by Artemisia reaching $80 \%$ of TLP, another unusual finding.

Fig. 1 Bin 1 (19.6 mya-11.6 kya). Age-weighted geographical centroid for Cannabis data is marked by a star. Background base map by Natural Earth, free open-source map data, https://www.naturalearthdata.com. 


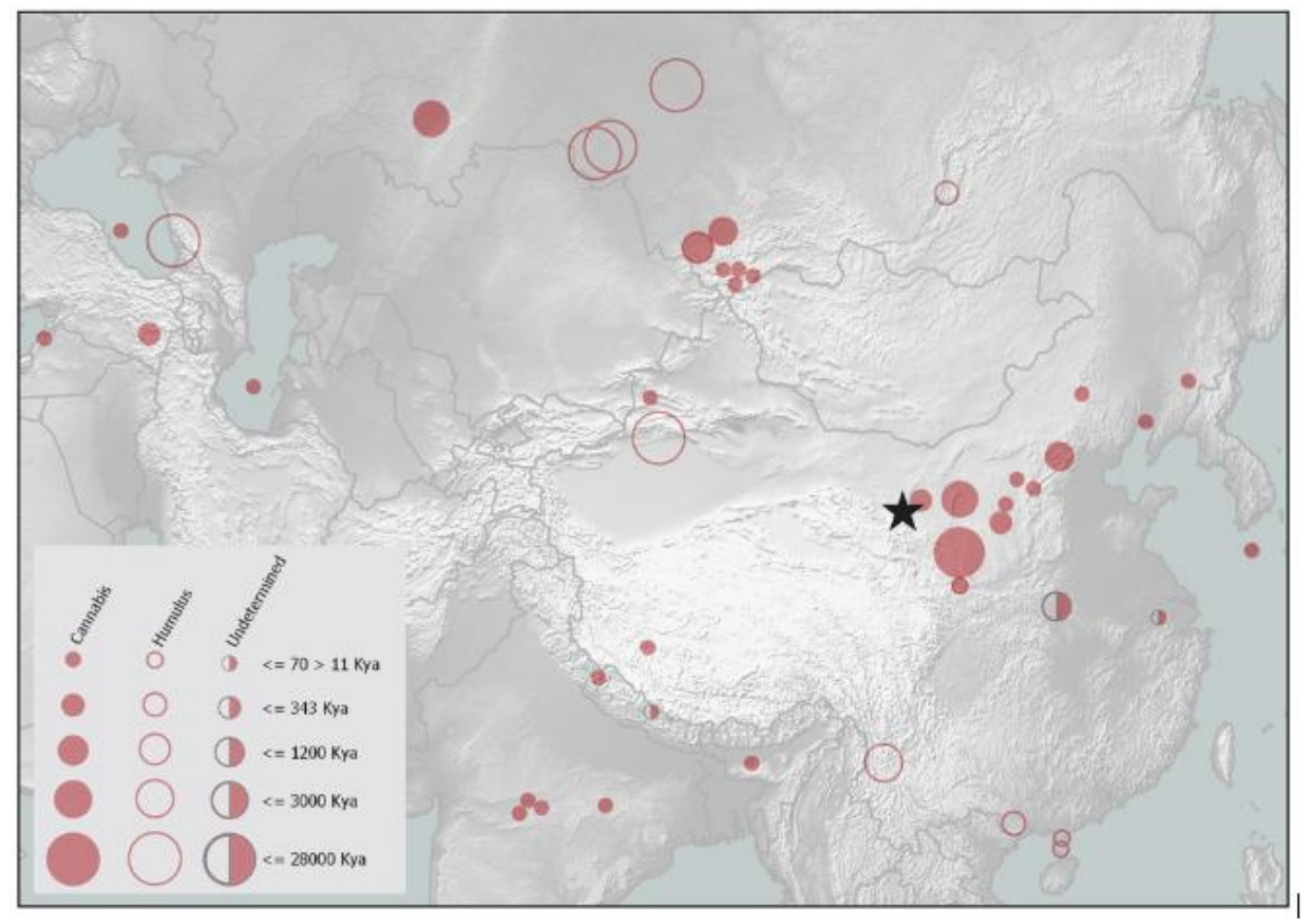

Bin 2 (11.5-5.0 kya, Fig 2). During the early Holocene, $C$ - $H$ pollen consistent with wild-type Cannabis occurs across Asia, from the Syrian and Anatolian steppes in the west to the Liaoning plains in the east, and from the Altai steppe in the north to the Central Highlands of India in the south, even the Horton Plains of Sri Lanka. No $\mathrm{C}-\mathrm{H}$ pollen consistent with cultivated Cannabis is detected in Bin 2. However, several archaeological sites with Cannabis artifacts fall into Bin 2. The oldest sites are in Japan (Chiba, 10,000 BP, Table S1 \#142) and China (Henan, 7850 BP, \#132). Somewhat younger artifacts are found in Japan (Fukui, 7200 BP, \#144; Aomori, 59004300 BP, \#146), and in China (Hunan, 6400-5300 BP, \#104; Gansu, 5000 BP, \#109; and Inner Mongolia 5000 BP,\#134).

Fig. 2 Bin 2 (11.5-5.0 kya). Background base map by Natural Earth, free open-source map data, https://www.naturalearthdata.com. 


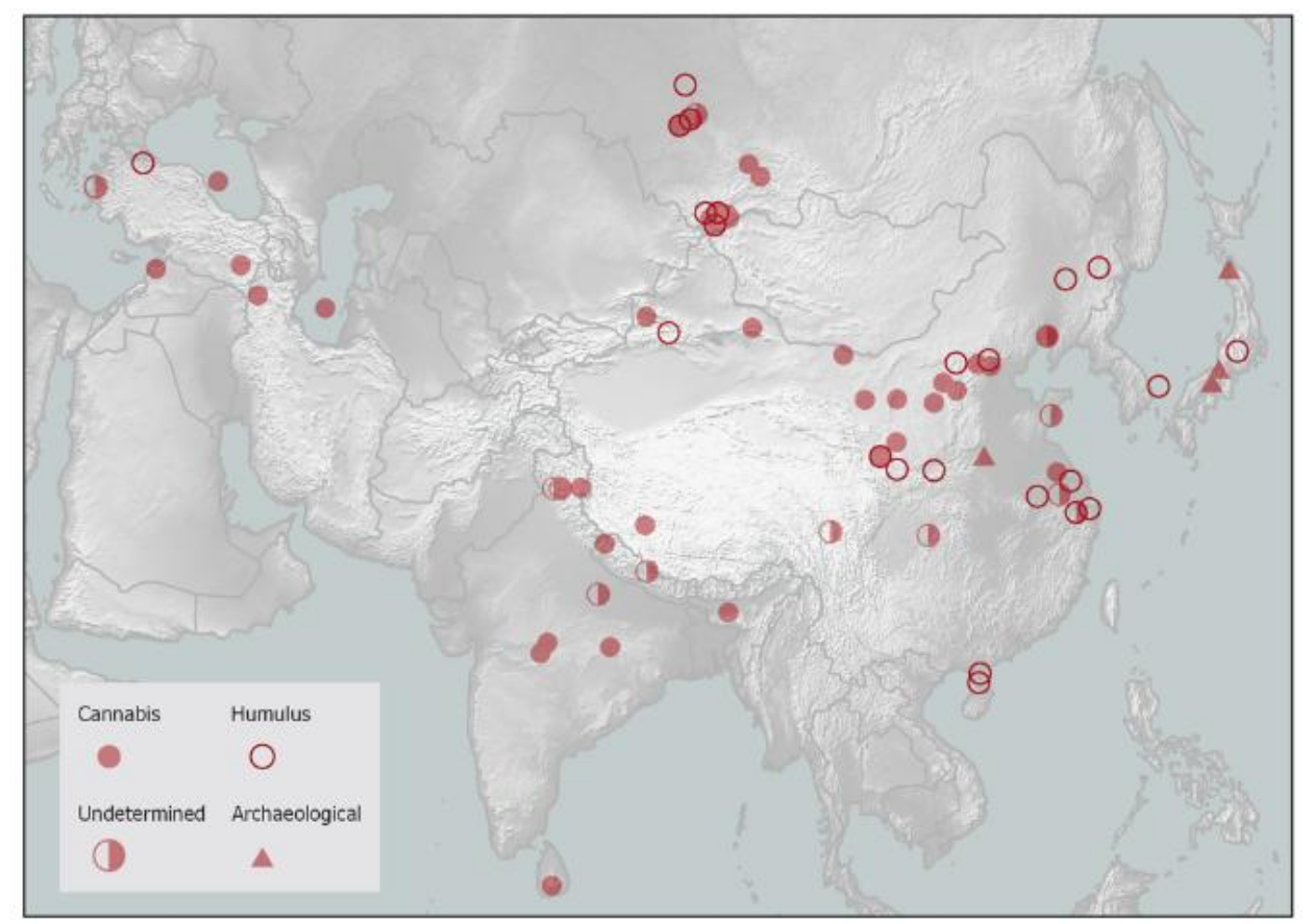

Bin 3 (4.5-0 kya, Fig 3) During the late Holocene, $C$ - $H$ pollen consistent with wild-type Cannabis occurs across the same range as Bin 2, excepting the loss of the Sri Lankan site. Pollen consistent with cultivated Cannabis appears at 35 sites. At eleven of those sites, Humulus in a forested environment gave way to land clearance and Cannabis cultivation, resulting in two symbols at the same site.

The oldest sites within this time slice are located in the lower Yangtze River basin, dating to 5330 BP (\#125) and 5000 BP (a retting site, with 15\% TLP, \#130). In Northwest China, cultivated Cannabis is located in Xinjiang (3720 BP, \#20; 2600 BP, \#129) and Qinghai (3000 BP, \#97). In East China, it appears in Shanxi (2800 BP, \#19). Outside of China, pollen consistent with cultivated Cannabis appears in Russia (3700 BP, \#155), Turkey (3200 BP, \#45; 2300 BP, \#153), Korea (3150 BP, a retting site, with 25\% TLP, \#139), and India (2500 BP, a retting site, with $28 \%$ TLP, \#71).

The oldest archaeological sites within this time slice are located in Gansu (5000-4700 BP, \#108, \#110), Qinghai (4200-3500, \#115, \#116), Inner Mongolia (3900-3400 BP, \#133), Shandong (3600-3000 BP, \#124), and Xinjiang (2800-2500 BP, \#135, \#136). Outside of China, relatively old sites are found in central Korea (4590-4240 BP, \#138), the Ganges River basin in 
India (4600-3200 BP, \#62-65), Japan (3500-3000 BP, \#147, \#148), Nepal (2400 BP, \#76), and the Russian Far East (2500 BP, \#79).

Fig. 3 Bin 3 (4.5-0 kya). Background base map by Natural Earth, free open-source map data, https://www.naturalearthdata.com/

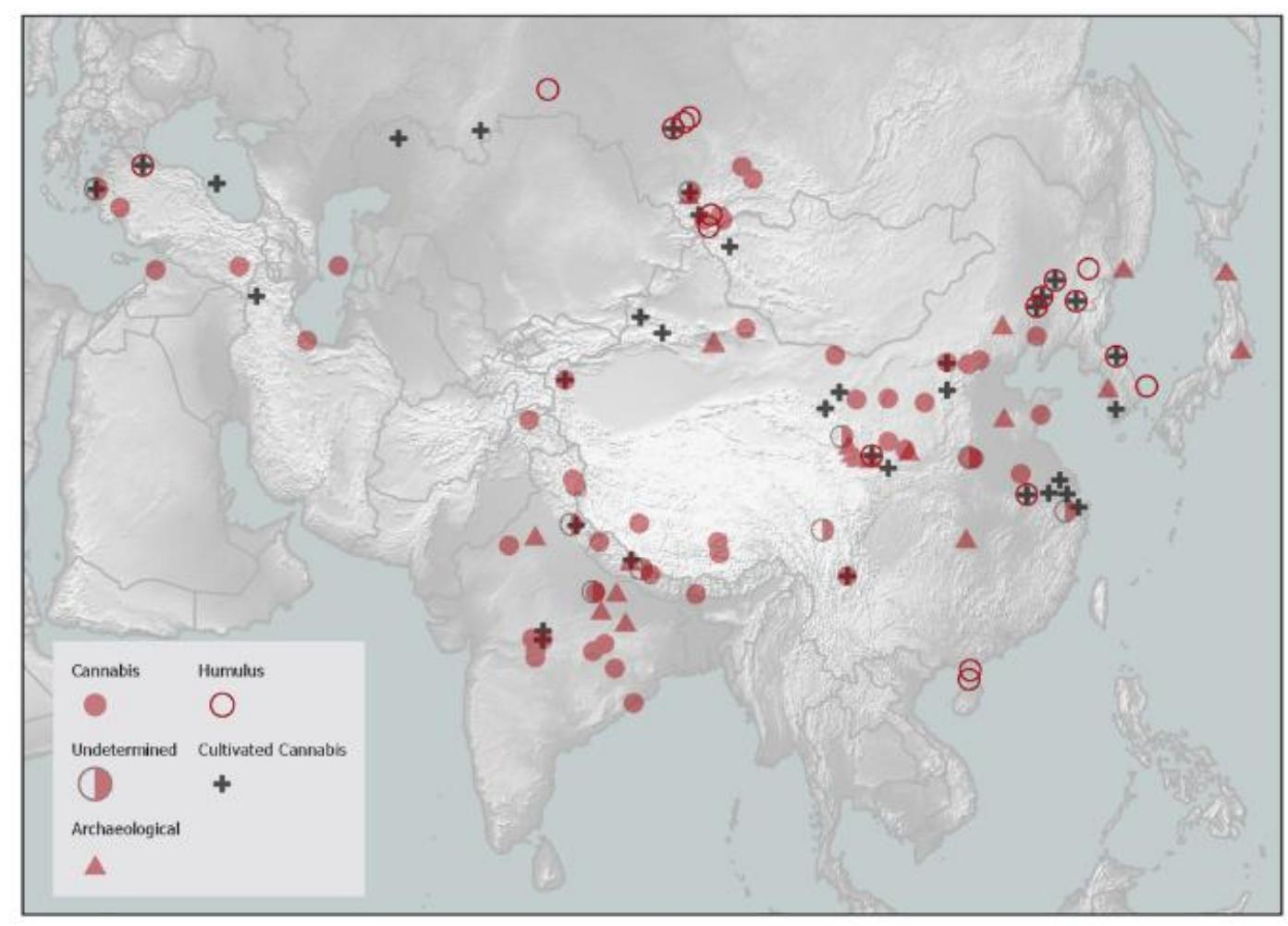

\section{Extrapolating into the Oligocene}

Next we deduced the location of $C$. sativa during the temporal "missing link" between its divergence date (27.8 mya) and oldest pollen (19.6 mya), using two sets of indirect data.

Bosboom et al. (2011) mapped an aridification zone arising at the Eocene-Oligocene boundary. The periphery of their zone is demarcated by the central Tarim Basin, southern Mongolia, and southeast of the Xining Basin. A best approximation of this paleogeographic zone was transferred to a modern map in Fig 4. The oldest $C$ - $H$ pollen consistent with Cannabis (site \#1) is located at the southeastern perimeter of the aridification zone (Fig 4).

Artemisia pollen during the late Eocene, Oligocene, and early/mid Miocene, based on data from Miao et al. (2011) is also mapped in Fig 4. The age-weighted centroid for these data is located within Bosboom's aridification zone. The Artemisia centroid, at $38.621^{\circ} \mathrm{N}, 102.205^{\circ} \mathrm{E}$, is located $60 \mathrm{~km}$ north of the Cannabis centroid shown in Fig. $1\left(38.186^{\circ} \mathrm{N}, 101.910^{\circ} \mathrm{E}\right)$. This 
amazing proximity is somewhat spurious, because the data set of Artemisia and Cannabis pollen somewhat reflects the distribution of palynologists, and accessibility to related strata, rather than a theoretically complete distribution of pollen.

Fig 4. Black ellipse: aridification zone arising at the Eocene-Oligocene boundary (Bosboom et al. 2011) transferred to a modern map. Age-weighted geographical centroid for Artemisia data is marked by a star. Background base map by Natural Earth, free open-source map data, https://www.naturalearthdata.com/

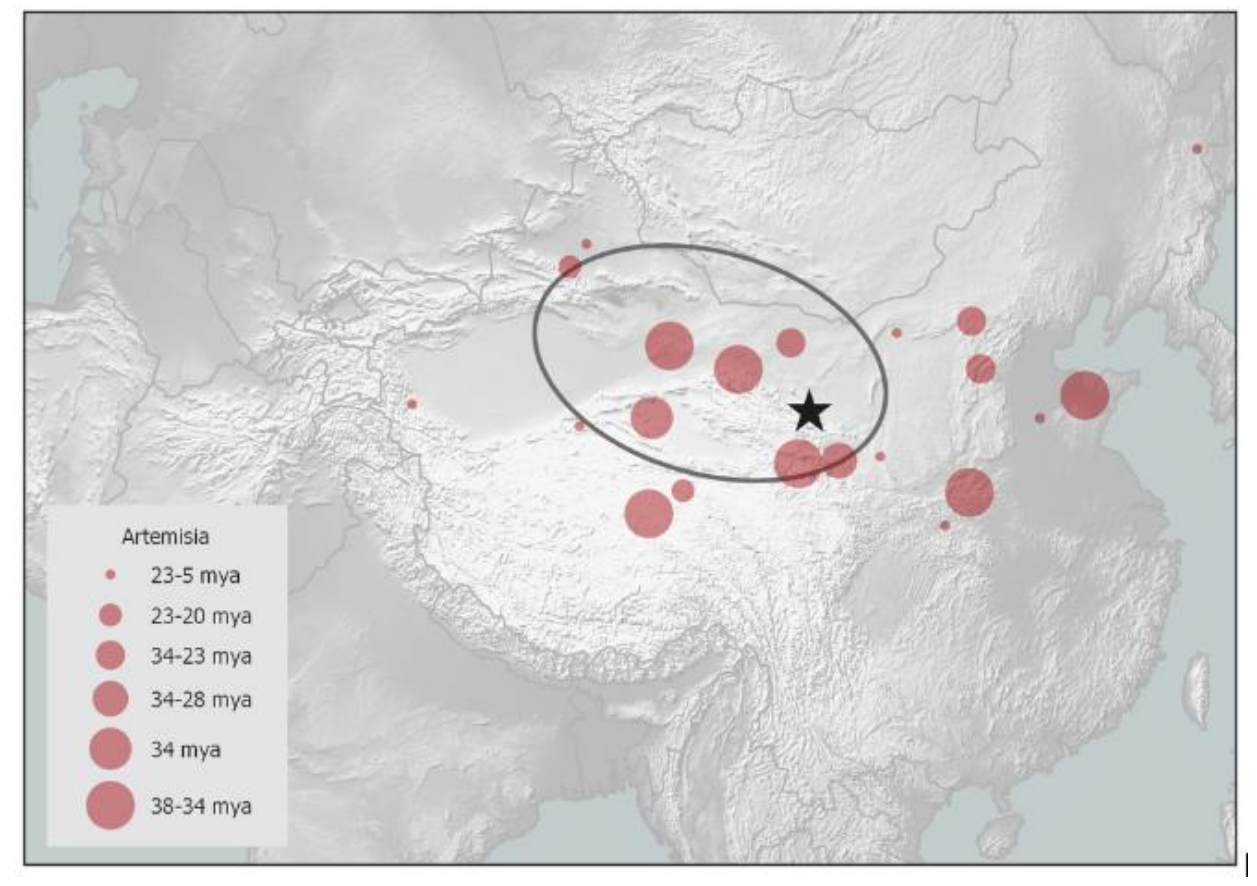

\section{Discussion}

The use of ecological proxies is an inferential method of differentiating Cannabis and Humulus pollen (McPartland et al. 2018). It offers a way to dissect Cannabis/Humulus and other collective names assigned by palynologists, due to the morphological similarities between Cannabis and Humulus pollen. However, the method is inherently probabilistic. The method also assumes that ecological niches of modern Cannabis, Humulus, PAC, and $A S P+$ can be extrapolated to past populations - the nearest living relative method (Mosbrugger and Utescher 1997).

At some sites dominated by AP pollen, we may have misidentified pollen signals of Cannabis cultivation as Humulus pollen. Pollen-based detection of early agriculture in densely forested sites often shares this conundrum (e.g., Tarasov et al. 2018). 
Cannabis pollen dating to the Miocene, Pliocene, and Pleistocene (Fig 1) has an ageweighted geographical centroid located in the northeastern Tibetan Plateau. However, the evolution of Cannabis predates these data. We applied Miao's Artemisia data as a proxy for the location of Cannabis during this "missing link." The weighted geographical centroid for the Artemisia data is also located in the northeastern Tibetan Plateau.

Thus we deduce the center of origin of Cannabis, along with that of her fellow traveler Artemisia, as the northeastern Tibetan Plateau, in the general vicinity of Qinghai Lake. The northeastern Tibetan Plateau, and the Cannabis and Artemisia pollen centroids, all fall within Bosboom's aridification zone. The oldest Cannabis pollen lies at the zone's periphery.

Zhang et al. (2018b) offered "low latitude" China as the Cannabis center of origin, based on haplotype data of 52 extant Cannabis accessions. They identified 25 haplotypes based on genetic variation in five cpDNA sequences ( $r p s 16$, psal-accD, rps11-rps8, rpl32-trnL, and ndhF-rpI32). Spatial analysis of molecular variance (SAMOVA) was used to determine the optimal number of haplogroups to divide the haplotypes, based on cpDNA variation and geographical coordinates. The data best fit $\mathrm{K}=3$; a phylogenetic tree placed one of the haplogroups basal, whose accessions came from Tibet ( $\mathrm{n}=7$ ) and Yunnan (6), as well as Inner Mongolia (3), Gansu (1), Guangxi (1), and Shandong (1).

Tibet and Yunnan embrace the southeastern portion of the Tibetan Plateau, so the estimation by Zhang and colleagues differs little from our own. Their analysis may have been biased by relatively recent genetic bottlenecks: Clarke and Merlin (2016) proposed that the Henduan Mountains, which constitute the Tibetan Plateau in southeastern Tibet, Yunnan, and Sichuan, served as a Pleistocene glacial refugium. Zhang and colleagues utilized the phylogram as a molecular clock, anchored by one fossil date (Aphananthe, 66 mya), and estimated that Cannabis and Humulus diverged 18.2 mya. However, low altitude China at that time was warmer and wetter than today, and covered by subtropical broad-leaved forests (Sun et al. 2011, Huang et al. 2016). This ecosystem would not have driven the evolution of a steppe plant like Cannabis, according to the nearest living relative method (Mosbrugger and Utescher 1997).

Cannabis expanded westward from its center of origin. $C$ - $H$ pollen consistent with Cannabis appeared in central Russia (the cis-Ural region; Table S1, \#156) by 1.5 mya. Further west, a fossil seed (achene) assigned to Cannabis in Bulgaria dated to 7.3-5.3 mya (Palamarev 1982). Cannabis expanded eastward from its center of origin. $\mathrm{C}$ - $\mathrm{H}$ pollen consistent with Cannabis 
appeared in northeastern Ningxia by 2.6 mya (Table S1, \#2), and Hebei by 1.2 mya (Table S1, \#3). By the end of the Pleistocene, all regions of China except South Central and Southwest China showed evidence of Cannabis.

FPSs in South Asia merit special attention: Humulus is not native to India; H. lupulus was introduced as a cultigen by British colonists in the 1840s (Hooker 1890, Khuroo et al. 2007). In many areas the plants proved maladaptive and did not reach maturity, because flowering time coincided with the onset of monsoons (Bakshi and Atal 1985). The introduction of non-native Humulus was also reported in Pakistan (Stewart 1971), Nepal (Sood and Thakur 2015), and Burma (Kress et al. 2003). Floras of Bangladesh and Thailand omit Humulus (Khan and Halim 1990, Santisuk 2015).

The absence of Humulus in South India provided a "beta test" of our algorithm-all $\mathrm{C}-\mathrm{H}$ pollen in South Asia should appear in pollen assemblages with a NAP/AP ratio $\geq 2$, consistent with Cannabis. In fact, several sites showed NAP/AP ratios approaching 1:1 (Table S1, \#42, \#57, $\# 59$, \#66, \#67). The $C$ - $H$ pollen at these sites may be due to long-distance transport, or represent small steppe communities surrounded by forests. One South Asian study found $C-H$ pollen in an assemblage with a NAP/AP ratio $\leq 2$ (\#71). This ratio would classify it as Humulus. But the $C-H$ percentage surged to $28 \%$, in the presence of crop pollen (Cerealia, Fagopyrum), which the algorithm identified as a hemp retting site, as did the original authors.

South Asian studies that recorded "Cannabis" in pollen assemblages with high AP values may have misidentified Celtis tree pollen. Notably, few South Asian FPSs included Celtis (family Cannabaceae) in their pollen diagrams. Three Celtis species are distributed in South Asia, C. australis, C. tetrandra, and C. wightii (Watt 1889, Hooker 1890). Celtis pollen grains resemble those of Cannabis - they are circular to elliptic, triporate with circular pores surrounded by an annulus, a thin exine, and smooth to verrucate surfaces. They have grain diameters whose sizes fall into the range of Cannabis and Humulus (see notes in Table S1, \#60). Several FPSs in India provided photomicrographs of Cannabis pollen; measurements based on their bar scales show grain sizes smaller than Cannabis (range 16-23 $\mu \mathrm{m}$, \#55, \#56), others are larger than Cannabis (range 70-180 $\mu \mathrm{m}, \# 57-59$ ).

Whether C. sativa is native to South Asia, versus an introduced species, is a long-standing debate (Hooker 1890, Watt 1889). Experts still argue whether C. sativa in the Himalaya is indigenous (Zhou and Bartholomew 2003) or a naturalized alien (Khuroo et al. 2007). We found 
pollen consistent with Cannabis appearing in India by 32.6 kya, which suggests an indigenous species, not introduced by humans. Cannabis pollen in South Asia by 32.6 kya begs the question of when it actually arrived. Early floristic exchanges between the Indian subcontinent and Asia were shaped by plate tectonics. As the Indian plate migrated towards the Asian plate, it made a "glancing contact" with Sumatra 57 mya, followed by Burma, and then a "hard collision" with Tibet 35 mya (Ali and Aitchison (2008). The "glancing contact" between continents resulted in floristic exchanges during the Eocene (Bande 1992, Morley 2003). The extant flora of India is often termed Indo-Malayan.

Cannabis arriving via Southeast Asia during the Eocene seems unlikely. Southeast Asian FPSs are bereft of $\mathrm{C} / \mathrm{H}$ pollen, and the Indo-Malayan exchange occurred before Cannabis evolved. The migrating Indian plate initiated uplift of the Tibet plateau ca. 40-35 mya - the primary cause of Bosboom's aridification zone. The Tibet uplift, followed by the Pamir uplift (35 mya) created a dispersal barrier between Central Asia and India. Perhaps the biogeographical dispersal patterns of related plants, which we discuss below, might help answer this question.

The oldest pollen signal of cultivated Cannabis identified by our methods dated to $5330 \mathrm{BP}$ (Table S1,\#125). Archaeological findings (seeds) predate this. Perhaps the seeds were collected from wild-type Cannabis. A Jōmon Culture site yielded the oldest seeds (Table S1 \#142). The seeds were found with other edible nuts and fruits, indicating food use. The Jōmon people made pottery but did not farm - their economy was based on wild resources and nut harvesting (Bleed and Matsui 2010). Contrary to this wild-type hypothesis, however, photomicrographs of the Jōmon seeds do not show wild-type traits, suggesting they were not only cultivated, but domesticated.

Serviceable fiber is not easily extracted from wild-type growth, which branches excessively. Densely-sown crops, with minimal branching, yield the best fiber. The clearest palynological signal of fiber use comes from FPSs with Cannabis pollen $\geq 15 \%$ of TLP, indicative of a retting site. The oldest retting site, dating to 5000 BP, is located in the Yangtze River delta (Table S1, \#130). The pollen identification is problematic, yet the authors discuss hemp retting as the source of their pollen surge, as do other authors (Table S1, \#71). Older non-palynological evidencecarbonized hemp fibers (excluded in this study) — dates to 5600 BP, in Henan (Zhang and Gao 1999). Intact rope and cloth dates to 5000 BP, in the Yangtze River delta (Zhou 1980). 
Archaeological evidence of ceremonial or drug use dates to 2700 BP, in Xinjiang (Table S1, $\# 135$, \#136). This interpretation is secured by the presence of processed leaves and female flowering tops, stored in a leather basket, wooden bowl, or earthenware pot.

\section{Cannabaceae biogeography}

The geographic ranges of related species may help locate an organism's center of origin (Crisci et al. 2003). The Humulus center of diversity lies in Southwest China: H. lupulus occurs in Sichuan; H. japonicus occurs in Sichuan, Yunnan, Chongqing, Guangxi, and Guizhou; $H$. yunnanensis is limited to Yunnan (Zhou and Bartholomew 2003). Small (1978) divided $H$. lupulus into five varieties, which collectively circumnutate the Northern Hemisphere at temperate latitudes. Gray (1859) noted the Humulus connection between East Asia and North America, foretelling the Bering land bridge theory.

Pteroceltis tatarinowii, the only extant species of that genus, is limited to China and Mongolia. However, fossils indicate that Pteroceltis is a relictual lineage that once had a wider geographic range, and similar to that of H. lupulus. Fossils of Pteroceltis tertiaria were found in Germany, and fossils of Pteroceltis knowltonii were found in the USA (Manchester et al. 2009).

Celtis is the largest genus in the Cannabaceae, with about 70 species, and 13 grow in China. Celtis also has the largest native range in the Cannabaceae, spanning temperate as well as tropical latitudes. In the Northern Hemisphere, Gray (1859) included Celtis in his proto-Bering land bridge theory. In the Southern Hemisphere, Celtis occurs in South America, Africa, and Australia (Stevens 2008). The oldest Celtis fossils (of Celtis aspera, 64-56 mya) have been found in the Russian Far East and the western USA (Manchester et al. 2002). This hints at an East Asian origin for the genus.

Trema and Parasponia are sometimes synonymized; a molecular study found both Trema and Parasponia paraphyletic, with no clear basal lineages (Yesson et al. 2004). Twelve Trema species grow in subtropical and tropical regions, in southern China, India, Southeast Asia, Africa, and Central America. China is the Trema center of diversity, with eight species growing there. Parasponia species do not occupy continental Asia; they are found in Indonesia, Papua New Guinea, Philippines, northern Australia, and some Melanesian and Polynesian islands.

Aphananthe species occur in China, Japan, Korea, India, Sri Lanka, Southeast Asia (including Philippines and Papua New Guinea), Mexico, Madagascar, and Australia. Fossils 
indicate a wider distribution, with finds in western Siberia, Germany, and the USA (Yang et al. 2017). Phylogenetic studies place Aphananthe basal to the rest of the Cannabaceae, hence it is the oldest genus (Yang et al. 2013, Zhang et al. 2018a). A fossil from Germany, Aphananthe cretacea, dates to 66-72.1 mya (Knobloch and Mai 1986).

Yang et al. (2017) reconstructed the biogeography of Aphananthe using DNA sequences and other molecular methods. They identified East Asia as the ancestral area of extant Aphananthe species. Dispersal took Aphananthe across the Bering land bridge into North America around 19.1 mya, and into South Asia by 18.1 mya. A route from East Asia to South Asia was not delineated. A. cuspidata occupies contiguous areas spanning East Asia and South Asia-Yunnan, Burma, and India — so that is the likely route.

In summary, most Cannabaceae genera have origins in East Asia. The ancestral distribution of $C$. sativa resembles that of $H$. lupulus, except $C$. sativa dispersed to South Asia, and $H$. lupulus crossed the Bering land bridge. We propose that the progenitor of Cannabis dispersed from East Asia to the northeastern Tibetan Plateau, where it underwent parapatric speciation in Bosboom's aridification zone, amidst Asia's first steppe community.

Cannabis dispersed from the Tibetan Plateau, first to the west (Russia and Europe) and then to the east (China). By the end of the Pleistocene, Cannabis spread throughout Asia, except for Southeast Asia. Thus wild-type Cannabis was available for people across Eurasia to bring into cultivation and domesticate. Several sites in southeastern Europe, mostly associated with the Yamnaya Culture, suggest autochthonous domestication in Europe (Clarke and Merlin 2013, Long et al. 2017, McPartland and Hegman 2018). Vavilov (1926) would have agreed, "it is probable that the cultivation of hemp arose simultaneously and independently in several places."

\section{References}

Ali JR, Aitchison JC (2008) Gondwana to Asia: plate tectonics, paleogeography and the biological connectivity of the Indian sub-continent from the Middle Jurassic through latest Eocene (166-35 Ma). Earth-Sci Rev 88:145-166

Andrek HY, Balog L, Sheer MV (2010) Humulus japonicus Siebold et Zucc. (Cannabaceae)новий адвентивний вид флори України. Укр. ботан. 67:438-445

Bakshi SK, Atal CK (1985) Hops in India. Council of Scientific and Industrial Research, Jammu-Tawi, India 
Balogh L, Dancza I (2008) Humulus japonicus, an emerging invader in Hungary. In: TokarskaGuzik B, et al. (eds) Plant Invasions: Human Perception, Ecological Impacts and Management. Backhuys Publishers, Leiden, pp. 73-79

Bande MB (1992) The Palaeogene vegetation of peninsular India (megafossil evidence). Palaeobotanist 40:275-284

Bleed P, Matsui A (2010) Why didn't agriculture develop in Japan? A consideration of Jomon ecological style, niche construction, and the origins of domestication. J Archaeol Method Theory 17:356-370

Bosboom RE, Dupont-Nivet G, Houben AJP, et al. (2011) Late Eocene sea retreat from the Tarim Basin and concomitant Asian paleoenvironmental change. Palaeogeogr Palaeoclimatol Palaeoecol 299:385-398

Botemma S, Kopaka K, Alexopoulos A (2003) The Late-Holocene vegetation history of Gavdos (Crete) in relation to long distance pollen dispersal: the Trypiti pollen diagram. In: Tonkov $\mathrm{S}$ (ed) Aspects of Palynology and Palaeoecology. Pensoft, Moscow, pp. 199-212

Clarke RC, Merlin MD (2013) Cannabis: Evolution and Ethnobotany. University of California Press, Berkeley

Crisci JV, Katinas L, Posadas P (2003) Historical Biogeography. Harvard University Press, Cambridge, MA

De Candolle AP (1883) Origine des Plantes Cultivées. Baillière, Paris

Dörfler W (1990) Die Geschichte des Hanfanbaus in Mitteleuropa aufgrund palynologischer Untersuchungen und von Großrestnachweisen. Prähistorische Zeitschrift 65:218-244

Dorofeev PI (1969) Миоценовая флора Мамонтовой горы на Алдане (Miocene Flora of the Mammoth Mountain on the Aldan). Izd-vo Akademia nauk SSSR, Leningrad

Dorofeev PI (1982) Cannabaceae. In Takhtajan AL, (ed) Ископаемые цветковые растения России и сопредельных государств, Т. 2 (Fossil Flowering Plants of Russia and Neighboring States, Vol. 2). Izd-vo Nauka, Leningrad, pp. 43-48

Eom BC, Kim JW (2017) Phytocoenosen and distribution of a wild tea (Camellia sinensis (L.) Kuntze) population in South Korea. Korean J Plant Res 30:176-190

Knobloch AH, Mai DH (1986) Monographie der Früchte und Samen in der Kreide von Mitteleuropa. Rozpr ustred ustavu Geol 47:1-219

Friedrich PA (1883a) "Cannabis oligocaenica nov. spec.," Beiträge zur Kenntniss der Tertiärflora der Provinz Sachsen. Schropp, Berlin, pp. 165-166

Friedrich PA (1883b) Atlas zu den Abhandlungen zur geologischen Specialkarte von Preussen den Thüringischen Staaten, Band IV, Heft 3. Schropp, Berlin

Fries M (1958) Vegetationsutveckling och odlingshistoria i Varnhemstrakten: en pollenanalytisk undersökning i Västergötland. Acta Phytogeogr Suec 39:1-63

Fröman I (1939) Die Hölzer des Rades und der Hopfenfund. In: Von Post L, Oldeberg A, Fröman I (eds) Ein eisenzeitliches Rad aus dem Filaren-See in Södermanland, Schweden. Wahlström \& Widstrand, Stockholm, pp. 89-98 
Kuhn D (1988) Textile Technology. In: Needham J, Wang L (eds) Science and Civilisation in China, Vol. 5, Part 9. Cambridge University Press, Cambridge, UK, pp. 1-520

Fuller DQ (2006) Agricultural origins and frontiers in South Asia: a working synthesis. J World Prehist 20:1-86

Gray A (1859) Diagnostic characters of new species of phanerogamous plants collected in Japan by Charles Wright, Botanist of the U.S. North Pacific Exploring Expedition. With observation upon the relations of the Japanese flora of that of North America. Mem Am Acad Arts Sci 6: 377-453

Hämeen-Anttila J (2006) The last pagans of Iraq: Ibn Wahshīyah and his Nabatean Agriculture. Brill Academic Publishers, Leiden

Hillig KW, Mahlberg PG (2004) A chemotaxonomic analysis of cannabinoid variation in Cannabis (Cannabaceae). Am J Bot 91(6): 966-975

Hooker JD (1890) The Flora of British India, Vol. 5. L. Reeve \& Co., London

$\mathrm{Hu}$ Z, Wu QA (1992) Studies of the rare and endangered plant species in the Yunnan region of China. In: Adams RP, Adams JE (eds) Conservation of plant genes: DNA banking and in vitro biotechnology. Academic Press, NY, pp. 267-272

Huang YJ, Jia LB, Wang Q, Mosbrugger V, et al. (2016) Cenozoic plant diversity of Yunnan: a review. Plant Divers 38:271-282

Jarolímek I, Kolbek J (2006) Plant communities dominated by Salix gracilis in Korean peninsula and Japan. Biologia Bratislava 61:63-70

Jeong HR, Kim HJ, Choi K, et al. (2012) Vegetation structure and distribution of forested wetland at public and private forests in Daegu City. J Agric \& Life Sci 46:69-84

Jiang HE, Wang L, Merlin MD, et al. (2016) Ancient Cannabis burial shroud in a Central Eurasian cemetery. Econ Bot 70: 213-221

Jung YK, Kim JW (1998) Syntaxonomy of mantle communities in South Korea. Korean J Ecol 21:739-750

Kim SS, Kim YS, Ha SG, Shin HT (2010) Dispersion of vascular plant in Daepyeong swamp, Korea. J Korean Nat 3:187-198

Khan MS, Halim M (1990) Flora of Bangladesh. No. 14, Cannabidaceae. Bangladesh Agricultural Research Council, Dacca

Khuroo AA, Rashid I, Reshi Z, et al. (2007) The alien flora of Kashmir Himalaya. Biol Invas 9:269-292

Kobayashi M, Momohara A, Okitsu S, et al. (2008) Fossil hemp fruits in the earliest Jomon period from the Okinoshima site, Chiba Prefecture. Shokuseishi kenkyū 16(1): 11-18

Kolbek J, Karolímek I (2008) Man-influenced vegetation of North Korea. Linzer Biol Beitr 40: 381-404

Kolbek J, Sádlo J (1996) Some short-lived ruderal plant communities of non-trampled habitats in North Korea. Folia Geobot 31(2):207-217

Kress WJ, DeFilipps RA, Farr E, et al. (2003) A checklist of the trees, shrubs, herbs, and climbers of Myanmar. Smithsonian Institution, Washington, DC 
Lee SJ, Ahn YH (2014) Study of vegetation structure about shrine forest in Jirisan National Park with regard to global warming. J Environ Sci Int 23:1863-1879

Lee CY, Liew PM (2010) Late Quaternary vegetation and climate changes inferred from a pollen record of Dongyuan Lake in southern Taiwan. Palaeogeogr Palaeoclimatol Palaeoecol 287:58-66

Lee HJ, Kim JH, Chun YM, Choung HL (1976) Synecology of the forest vegetation of Yeongjongo. Korean J Ecol 26:223-236

Lee KS, Cho MG, Moon HS, Jeon KS (2013) The list of vascular plants at Junam wetland in Changwon City. Korean J Agric For Meteorol 15:67-75

Li HL (1974) An archaeological and historical account of cannabis in China. Econ Bot 28:437448

Li XL, Hao QZ, Wei MJ, et al. (2017) Phased uplift of the northeastern Tibetan Plateau inferred from a pollen record from Yinchuan Basin, northwestern China. Sci Rep 7:18023

Long T, Wagner M, Demske D, et al. (2017) Cannabis in Eurasia: origin of human use and Bronze Age trans-continental connections. Veget Hist Archaeobot 26:245-258

Lynch RC, Vergara D, Tittes S, et al. (2016) Genomic and chemical diversity in Cannabis. Crit Rev Plant Sci 35: 349-363

Manchester SR, Akhmetiev MA, Kodrul TM (2002) Leaves and fruits of Celtis aspera (Newberry) comb. nov. (Celtidaceae) from the Paleocene of North America and Eastern Asia. Int J Plant Sci 163: 725-736

Manchester SR, Chen ZD, Lu AM, et al. (2009) Eastern Asian endemic seed plant genera and their paleogeographic history throughout the northern hemisphere. J Syst Evol 47:1-42

Maximovich CJ (1859) Primitiae florae Amurensis. Versuch einer Flora des Amur-Landes. Kaiserlichen Akademie der Wissenschaften, St. Petersburg

McPartland JM (2018) Cannabis systematics at the levels of family, genus, and species. Cannabis Cannabinoid Res 3(1):203-212

McPartland JM, Hegman W (2018) Cannabis utilization and diffusion patterns in prehistoric Europe: a critical analysis of archaeological evidence. Veget Hist Archaeobot 27:627-634

McPartland JM, Guy GW, Hegman W (2018) Cannabis is indigenous to Europe and cultivation began during the Copper or Bronze age: a probabilistic synthesis of fossil pollen studies. Veget Hist Archaeobot 27:635-648

Mercuri AM, Accorsi CA, Mazzanti MB (2002) The long history of Cannabis and its cultivation by the Romans in central Italy, shown by pollen records from Lago Albano and Lago di Nemi. Veget Hist Archaeobot 11:263-276

Miao YF, Meng QQ, Fang XM, et al. (2011) Origin and development of Artemisia (Asteraceae) in Asia and its implications for the uplift history of the Tibetan Plateau: a review. Quat Int 236:3-12

Morley RJ, Dick CW (2003) Missing fossils, molecular clocks, and the origin of the Melastomataceae. Am J Bot 90:1638-1644 
Mosbrugger V, Utescher T (1997) The co-existence approach - a method for quantitative reconstructions of Tertiary terrestrial palaeoclimate data using plant fossils. Palaeogeogr Palaeoclimatol Palaeoecol 134:61-86

Ni J, Yu G, Harrison SP, Prentice IC (2010) Palaeovegetation in China during the late Quaternary: Biome reconstructions based on a global scheme of plant functional types. Palaeogeogr Palaeoclimatol Palaeoecol 289:44-61

Oh HK, Beon MS, Kim YH (2010) Classification by plants communities of the Wi-do (Island), Buan-focused on Jilli evergeen forest, Chido wetland, and Seokgeum. J Korean Nat 3:159169

Oh YJ, Yoo JH, Moon BC, et al. (2008) Habitat characteristic and community structures of Humulus japonicus in Korea's middle region. Korean J Environ Agric 27:72-79

Palamarev E (1982) Неогенската карпофлора на Мелнишкия басейн. Paleontol Stratigr Lithol 16:3-43

Pételot PA (1954) Les plantes médicinales du Cambodge, du Laos et du Viêtnam. Publisher not identified, Saigon

Quamar MF, Bera SK (2017) Pollen records related to vegetation and climate change from northern Chhattisgarh, central India during the late Quaternary. Palynology 41:17-30

Russo EB, Jiang HE, Li X, et al. (2008) Phytochemical and genetic analyses of ancient cannabis from Central Asia. J Exper Bot 59:4171-4182

Santisuk T, Balslev H (2015) Flora of Thailand, Vol. 13, Part 1. Achariaceae, Adoxaceae, Cannabaceae, Caprifoliaceae, Ericaceae, Salicaceae \& Ulmaceae. Forest Herbarium, Depart of National Parks, Wildlife and Plant Conservation, Bangkok

Sawler J, Stout JM, Gardner KM, et al. (2015) The genetic structure of marijuana and hemp. PLoS ONE 10(8): e0133292

Small E (1978) A numerical and nomenclatural analysis of morpho-geographic taxa of Humulus. Syst Bot 3:37-76

Small E, Cronquist A (1976) A practical and natural taxonomy for Cannabis. Taxon 25(4): 405435

Sood SK, Thakur R (2015) Herbal resources of India and Nepal. Scientific Publishers, Jadhpur, India

Song JS, Song SD (1996) A phytosociological study on the riverside vegetation around Hanchon an upper stream of Nak-tong River. Korean J Ecol 19:431-451

Song YH, Cohen DJ, Shi JM, et al. (2017) Environmental reconstruction and dating of Shizitan 29, Shanxi Province: an early microblade site in north China. J Archaeol Sci 79:19-35

Steward RR (1971) Flora of West Pakistan. Fakhri, Karachi

Sun BN, Wu JY, Liu YS, et al. (2011) Reconstructing Neogene vegetation and climates to infer tectonic uplift in western Yunnan, China. Palaeogeogr Palaeoclimatol Palaeoecol 304:328336

Sun JM, Ni XJ, Bi SD, et al. (2014) Synchronous turnover of flora, fauna, and climate at the Eocene-Oligocene boundary in Asia. Sci Rep 4:7463 
Tarasov PE, Savelieva LA, Long T, et al. (2018) Postglacial vegetation and climate history and traces of early human impact and agriculture in the present-day cool mixed forest zone of European Russia. Quat Int, Epub before print

Vavilov NI (1926) The origin of the cultivation of "primary" crops, in particular cultivated hemp. Труды по прикладной ботанике, генетике и селекции 16:221-233

Wang WM (1996) On the origin and development of steppe vegetation in China. Palaeobotanist 45: 447-456

Watt G (1889) A Dictionary of the Economic Products of India, Vol. 2. Calcutta Office of the Superintendent of Government Printing, Allen, London

Watt G (1890) A Dictionary of the Economic Products of India, Vol. 4. Calcutta Office of the Superintendent of Government Printing, Allen, London

Wilson DG (1975) Plant remains from the Graveney boat and the early history of Humulus lupulus L. in W. Europe. New Phytol 75:627-648

Yang MQ, van Velzen R, Bakker FT, et al. (2013) Molecular phylogenetics and character evolution of Cannabaceae. Taxon 62:458-472

Yang MQ, Li DZ, Wen J, et al. (2017) Phylogeny and biogeography of the amphi-Pacific genus Aphananthe. PLoS ONE 12(2): e0171405

Yesson C, Russell SJ, Parrish T, et al. (2004) Phylogenetic framework for Trema (Celtidaceae). Plant Syst Evol 248:85-109

Zecchetto S, De Blasio F (2007) Sea surface winds over the Mediterranean Basin of satellite data (2000-04): Meso- and Local-scale features on annual and seasonal time scales. J Appl Meteorol Climatol 46:814-827

Zhang SL, Gao HY (1999) 䓠阳青台遗址出土的丝麻品观察与研究 (Observation and study of silk and hemp recovered from Qingtai archaeological site, Xingyang). Zhōngyuán Wénwù 3:10-16

Zhang HL, Jin JJ, Moore MJ, et al. (2018a) Plastome characteristics of Cannabaceae. Plant Divers 40:127-137

Zhang QY, Chen X, Gou HY, et al. (2018b) Latitudinal adaptation and genetic insights into the origins of Cannabis sativa L. Front Plant Sci 9:1876

Zhou Z, Bartholomew B. (2003) Cannabaceae. In: Wu ZY, Raven PH, Hong DY (eds) Flora of China, Vol. 5. Science Press, Beijing, pp. 74-75

Zhou B, Shen CD, Sun WD, et al. (2007) Elemental carbon record of paleofire history on the Chinese Loess Plateau during the last $420 \mathrm{ka}$ and its response to environmental and climate changes. Palaeogeogr Palaeoclimatol Palaeoecol 252:617-625

Zhao HB, Chen FD, Chen SM, et al. (2010) Molecular phylogeny of Chrysanthemum, Ajania and its allies (Anthemideae, Asteraceae) as inferred from nuclear ribosomal ITS and chloroplast trnL-F IGS sequences. Plant Syst Evol 284:153-169 